\title{
NUAK1 wt Allele
}

National Cancer Institute

\section{Source}

National Cancer Institute. NUAK1 wt Allele. NCI Thesaurus. Code C126572.

Human NUAK1 wild-type allele is located in the vicinity of $12 \mathrm{q} 23.3$ and is approximately

$77 \mathrm{~kb}$ in length. This allele, which encodes NUAK family SNF1-like kinase 1 protein, is involved in serine/threonine phosphorylation. 